\title{
HETEROSIS AND GENE ACTION FOR PARTIAL DIALLEL CROSSES IN COTTON \\ I. COTTON INSECT RESISTANCE AND MULTIVARIATE ANALYSIS FOR TRAITS RELATED TO INSECT RESISTANCE
}

\author{
EL- FEKI, T. A. ${ }^{1}$, R. K. HARB ${ }^{2}$ AND AZIZA M. SULTAN ${ }^{1}$ \\ 1. Cotton Research Institute, $A R C$, Giza \\ 2. Department of Botany, Faculty of Agriculture, Cairo University, Giza
}

(Manuscript received 17 November 2008)

\begin{abstract}
This investigation was carried out at Giza Experimental Station, Agricultural Research Center, Egypt in 2002, 2003 and 2004 growing seasons using partial diallel crosses system among eight parents to estimate heterosis, potence ratio, inbreeding depression, combining ability, gene action and heritability for infestation percentage.

Multivariate analysis was used to determine the intercorrelation between morphological traits and anatomical characters, with infestation percentage of bollworm to assess the importance of these traits. The results indicated that the damage was more in $F_{1} s$ than parents, Positive and significant inbreeding depression in $F_{2}$ except for (G.90 x Okra leaf). G.C.A and S.C.A variances were highly significant in both generations with more importance for non additive gene action. The parents Nectariless, Okra leaf and G.90 were good combiners for decreasing infestation percentage. The broad sense heritability values were high in both generations, while narrow sense heritability values was moderate in $F_{1}$. Significant negative correlations were observed between infestation percent and mean petiole diameter, number of xylem rows of petioles, placenta thickness and central leaf lobe index, while significant positive correlations were found in cortex thickness / stem , bract index and plant height. The factor analysis revealed that the traits of central lobe index , placenta thickness, lobing index, number. of xylem of petiole and mean petiole diameter have inter-relationship with infestation percent of insect.
\end{abstract}

\section{INTRODUCTION}

Cotton has been a major source of the national income of Egypt. Recently the cotton cultivated area was drastically decreased due to reduction in income obtained from cotton cultivation. This reduction in income was attributed to the high cost of pest control during cotton growth season and the yield and quality losses caused by pink bollworm and other insects. EL-Zik and Thaxton (1989) reported that the resistance to insect was associated with several plant morphological traits such as okra leaf, frego bract nectariless, dense hair ,glabrus and red plant colour. Ali (2006) reported that reduction rate of number of pink bollworm ranged from $71.44 \%$ for (G.88 X Okra leaf) to $81.69 \%$ for (G.90 X Hairy leaf ).Darweesh (2006) reported that 
$\mathrm{F}_{2}$ and $\mathrm{BC2}$ Plants of cross (G.90X Mar GN-8) gave the highest reduction percentage of pink bollworm infestation percent. Meanwhile the reduction percentages for $F_{2}, B C 2$, $F_{1}$ and $B C 1$ in crosses were higher than for Egyptian cotton variety (G.90). Max (2004) found that multivariate techniques principle components revealed leaf area and leaf shape index were important components among the studied traits related to insect resistance in cotton, also the found second Pc axis separated two lines Nectariless Okra leaf from both Giza 83 and Giza 85 parents and their $F_{1}$ s.

The primary objective of this study is to determine the heterosis, gene action and heritability for infestation percentage as well as the inercorrelation between morphological traits and anatomical characters, with infestation percentage of bollworm to assess the importance of these traits in the resistance for pink bollworm.

\section{MATERIALS AND METHODS}

The material of this investegation inclucled five Egyptian cotton cultivars of $G$. barbadense, L, namely G.91, G.90, G.70, G.88 and Suvin and Upland cotton lines insect resistant $G$. hirsutum $L$ namely Okra leaf , Frego bract, and Nectariless. The crosses were made in 2002 at Giza Experimental Station using a partial diallel mating design including the eight parents. In $2003 F_{1}$ plants were grown to produce selfed seed of $F_{2}$ progeny and crossing among the eight parents to produce more $F_{1}$ seeds. In 2004 season, the eight parents with the $12 F_{1}$ and $F_{2}$ hybrids were grown in a randomized complete block design with three replications. The parents were treated as random effect. The rows were $4 \mathrm{~m}$. long and $60 \mathrm{~cm}$. between rows, hills were spaced $20 \mathrm{~cm}$ within rows seedling stage plants were thinned to two plants / hill. Standard cultural methods were applied. The measurements were taken on ten guarded individual plants in each plot for the morphological characters, lobing index, bract index, central leaf lobe index $(\mathrm{cm})$, size of leaf nectarines (The measurement were in $\mathrm{mm}$ and transformed to its Log.), number of locules / boll, plant height (cm.) at picking time and infestation percentage: the ratio between number of infested locules per plant / total number of locules per plant.

Anatomical traits including specimens for the anatomical study, were taken from stems, (the visible internode below shoot apex), median leaf (petiole and blade) of the main stem in addition to the boll. Samples were taken at the age of 79 days from the eight parents and the twelve $F_{1}$ hybrids, sections were measured by micrometer lens, to detect histological measurements and counts of the studied genotypes. Averages of three readings were calculated. 


\section{Statistical and genetic analyses}

1- The analysis of variance was calculated according to F- tests by Cochran and Cox (1957).

2- Estimation of general and specific combining ability effects for partial diallel by Chaudhary et. al. (1977).

3- Heterosis percentages were calculated relative to mid- parents (M.P.) and better parents (B.P.):

H. $($ M.P. $)=$ F1 -M.P. /M.P. $\times 100$.

H. (B.P.) = F1 - B.P / B.P. $x 100$.

4- Inbreeding depression (I.D \%.):

$$
\text { I.D. }=\frac{\overline{\mathrm{F}}_{1}-\overline{\mathrm{F}} 2}{\overline{\mathrm{F}}_{1}} \times 100
$$

5- Potence ratio (p) Calculated from the formula given by Smith (1952) to determine the degree of dominance. $\mathbf{P}=\frac{\overline{\mathbf{F}_{1}}-\overline{\mathbf{M}} \cdot \mathbf{P}}{1 / 2\left(\mathbf{P}_{2}-\mathbf{P}_{1}\right)}$

The significance of heterosis and inbreeding depression were T. tested by:

L.S.D, mid-parents heterosis $=t_{x} \times \sqrt{\frac{3 \mathrm{MSe}}{2 \mathrm{r}}}$

L.S.D, better-parent and inbreeding depression $=t_{x} \times \sqrt{\frac{2 \mathrm{MSe}}{r}}$

6- Heritability estimate in broad sense $\left(h^{2} b_{s} \%\right)$ and narrow sense $\left(h^{2} b_{n} \%\right)$ were calculated by Verhalen and Murray (1969), it was measured for all the studied characters in $F_{1}$ and $F_{2}$ generations by the formulae:

$$
\begin{aligned}
& \mathbf{F}_{\mathbf{1}}: \mathbf{h}^{\mathbf{2}} \mathbf{b}_{\mathbf{s}} \%=[(1 / 2 A+D) /(1 / 2 A+1 / 2 D+E)] \times 100 . \\
& \mathbf{h}^{\mathbf{2}} \mathbf{b}_{\mathbf{n}} \%=[1 / 2 A /(1 / 2 A+1 / 2 D+E)] \times 100 . \\
& \mathbf{F}_{\mathbf{2}}: \mathbf{h}^{\mathbf{2}} \mathbf{b}_{\mathbf{s}} \%=[(1 / 4 A+1 / 2 D) /(1 / 4 A+1 / 2 D+E)] \times 100 . \\
& \mathbf{h}^{\mathbf{2}} \mathbf{b}_{\mathbf{n}} \%=[1 / 4 A /(1 / 4 A+1 / 2 D+E)] \times 100 .
\end{aligned}
$$

Where: $\mathrm{A}=$ Additive gene effect. $\mathrm{D}=$ Dominance gene effects, $\mathrm{E}=$ Environmental effect.

7. Multivariate analysis

The factor analysis methods, discussed by Cattle (1965) consisted of the reduction of large numbers of correlated variables sed smaller numbers of cluster variables called (Factors). 


\section{RESULTS AND DISCUSSION}

\section{Infestation percentage and multivariate analysis}

\section{a) Infestation percentage}

\section{Mean squares and combining ability}

The analysis of variance of the eight parents and their $F_{1}$ and $F_{2}$ partial diallel hybrids for infestation percentage is presented in Table (1). Data showed that mean squares of genotypes of parents, $F_{1}$ and $F_{2}$ were highly significant indicating that the damage was different due to genotype variability and then, the genetic material was valid to proceed for further analysis. Also, the results in Table (1) showed highly significant interactions to mean squares of parents' vs crosses, and $F_{1} v s F_{2}$ indicating that the average heterosis and inbreeding depression over all crosses, were significant for this trait. The variance of $F_{1}$ and $F_{2}$ hybrids were partioned into main effects, general combining ability (G.C.A) which equal half the additive genetic variance and specific combining ability (S.C.A) which equal the dominance gene effects. Data in Table (2) revealed that both G.C.A and S.C.A variances were significant for this trait in both generations. These results suggested the presence of both additive and non additive in $F_{1}$ with more magnitude of additive gene effect. Meanwhile the additive in $F_{2}$ is equivalent to zero value due to the negative values. These results were in partially agreement with that obtained by Seif El-Nasar (1987). The data in Table (2) also revealed that narrow sense heritability values were moderate in $F_{1}$ generation, while the value of heritability in $\mathrm{F}_{2}$ was neglectful value.

\section{Performance of parents and general combing ability effects}

Table (3) showed mean Performance and G.C.A effects for eight parents. The mean value of parents showed differences with range of 7.71 for Nectariless strain to 23.26 for Giza 70. The results showed that Nectariless and Okra leaf exhibited little damage for bollworm. Comparable results were obtained by Abd El-Bary et. al. (1980), Benedict et. al. (1981), Meredith et. al. (1996 ) and Ali (2006).

The data in Table (3) suggested that Nectariless, G.91 and G.90 were good combiners for reducing the infestation percentage in $F_{1}$ generation, while Okra leaf was good combiner for decreasing the infestation percentage in $F_{2}$.

\section{The Performance of $F_{1} s$ generation, heterosis and potence ratio}

Table (3) showed that the two hybrids of (G.90 x Okra leaf) and ( $G .70 \times$ Nectariless) exhibited lower values of infestation percentage. While (G.70 $x$ Nectariless) exhibited the largest negative heterotic effect (desirable effect) and (G.90 
x Okra leaf) exhibited non significant heterotic effect. Both hybrids showed that potence ratio was less than unity indicating partial dominance. These results suggested that the above two hybrids were better for infestation percentages. Most of other crosses exhibited significant and positive heterotic effect and the potence ratio were more than unity suggesting over dominance. The results indicated that damage were more in $F_{1} s$ than in their parents.

\section{The Performance of $F_{\mathbf{2}}$ generation and inbreeding depression}

Table (3) presents means of $F_{2}$ performance and inbreeding depression, the data showed that mean performance of $F_{2}$ were less than mean performance of $F_{1}$. The ranges of mean performance were 6.65 for (G.88 x Nectariless) to 15.57 for (G.90 x Frego bract).

The data showed that all hybrids exhibited positive and significant inbreeding depression effects except for (G.90 x Okra) .which indicate that the damage in $F_{2}$ was less than damage in $F_{1}$ and parents. These results confirm that this cross was better for low damage by bollworm.

\section{b) Correlation between the infestation percentage and other morphological and anatomical traits}

Simple correlation coefficients between infestation percentage and 18 variables including morphological and anatomical traits are shown in Table (4). The results clearly indicate that the mean petiole diameters, number of xylem row / bundle of petiole, placenta thickness and central leaf lobe index were significant and negatively correlated with infestation percentage with values of $-0.524,-0.593,-0.615$ and 0.531 , respectively. Significant and positive association was found between infestation percentage and cortex thickness, bract index and plant height with values of 0.560 , 0.435 and 0.510 , respectively.

\section{c) Principal components analysis}

Multivariate technique using Principal Components Analysis, PCA was performed to extract important components of variation, resolving phenotypic measurements into fewer and easily visualized diameters that affect the character under study .PCA seemed to elucidate patterns of variation in morphological, anatomical and infestation percentage attributes to obtain the initial factors solution using eigen values, which measured the exploited variance associated with each variable factor (Hair et. al. 1987). Therefore, principle components analysis was conducted on eight characters related to insect resistance, earliness traits and ten anatomical traits. In this analysis nineteen variables axes existed and only those which are exhibited high multivariate 
variances were considered. Thus, the first four principal components axes accounted for more than $72.6 \%$ of total variance of all characters. The joint values and their contribution toward the total variation associated with the first four principal components axes as well as eigen vectors of each characters are given in Table (4). Principal components showed that the first principal components axis accounted for about $35 \%$ of the multivariate variation among genotypes. While the next three axes accounted for about $37 \%$ and were followed by three axes (fifth, sixth and seventh) which accounted for about $17 \%$ of the total variance. In this respect, Gutierrez et. al. (1988) reported that the first three principal components accounted for $54 \%$ of the total variability among twenty G. hirsutum, cultivars for 16 studied traits. Likewise, Brown (1991) studied PCA, of cotton cultivars based on 17 agronomic and fiber characters measurements and reported that the first three PCA accounted for no less than $62 \%$ of total variance of all characters which agreed with these finding. While You et. al. (1998) selected three $\mathrm{Pc}_{5}$ and found that their accumulative contribution percentage of variance accounted for $85 \%$. The relative magnitude of the eigen coefficient of each character related to the first four axes from the components analysis which might provide an interpretation for each component axis. Though no clear guide lines existed to determine the significance coefficients $>0.3$ treat as having a large enough effect to be considered important (Hair et. al. 1987). The sign of the eigen coefficient is being irrelevant and in fact arbitrary, though negatively correlated characters will be generally of opposite signs on given axes. Each character was an important source of variation in at least one principal component axis, because each of PC axes, was given equal weight have greater importance in determining plant phenotypes than others (Hair et. al. 1987).

Table (5) Showed that the first three axis were of equal importance and account for about $58 \%$ of the total variance, while the fourth axis was less important accounted for about $14.7 \%$. The PCA axes showed that the traits central leaf lobe index, lobing index, placenta thickness, cortex thickness /stem, number of locules / boll and infestation percentage were the primary sources of variation having the largest coefficient in the first Pc axis. These results suggested that inter-correlation is implied among these traits with high coefficients for these traits on some axis (Brown 1991). However bract index, size of leaf nectaries and days to first flower appeared to have the second largest coefficient in the first Pc axis. Morewhile, the three characters: bract index, size of leaf nectaries and days to first flower as well as number of xylem row / bundle of leaf, number of locules, blade thickness and lint yield exhibited the largest coefficients in the second Pc axes. The third principal component accounted for about $19 \%$ of total variance of all traits, the larger coefficient are mean 
pith diameter, mean stem diameter, mean bundle diameter / stem, plant height and locules wall thickness. The forth principal component accounted $14.7 \%$, for the number of xylem row of petiole, means petiole diameter, infestation percentage and plant height. These results suggested that an inter-correlation is implied between the infestation percentage and number of xylem row / petiole, mean petiole diameter and plant height. The factor analysis provided additional information, however by grouping the 19 variables into four main factors with the first three groups being of equal importance. The first axis indicated the importance of central leaf lobe index, lobing index and placenta thickness and the second axe indicated the importance of number of xylem row / bundle of leaf and bract index, while the third axe indicated the importance of mean pith diameter, mean stem diameter and cortex thickness/stem. The forth axe indicated that importance for the number of xylem row / bundle of petiole and mean petiole diameter. Mean stem diameter and mean pith diameter seemed to be the most important variable had a large communality value $h^{2}=0.894$, 0.877 respectively.

The results of multivariate were in harmony with the result of correlation coefficient between the infestation percentage and number of xylem rows / bundle of petiole, placenta thickness and central leaf index, cortex thickness, bract index and plant height.

It could be conculded that traits central lobe index, placenta thickness, lobing index, number of xylem rows and mean petiole diameter have interrelationshipe infestation percentage by insects. 


\section{REFERENCES}

1. Abd El-Bary, A. A., M. A. Omar and M. M. Shahbander. 1980. Evaluation of bollworm resistance in some Egyptian cotton cultivars and strains. Alex. J. Agric. Res., 28 (1): 91-95

2. Ali, S. E. 2006. Relationship of some cotton genotypes with insect resistance. Ph.D. Thesis Env. Studies and Res. Inst, Ain-Shams Univ., Cairo, Egypt, 106 pp.

3. Benedict, J. H., T. F. Leigh, A. H. Hyer and P. F. Wynholds. 1981. Nectariless cotton, effect on growth, survival and Fecundity of Lygus Bugs. Crop Sci., 21: 28 30

4. Brown, J. S. 1991. Principal component and cluster analysis of cotton cultivars variability across the cotton belt. Crop Sci. 31: 915 - 921.

5. Cattle, R. B. 1965. Factor analysis an introducing to essential. The purpose and

6. underlying models. Biometrics., 21: $196-215$.

7. Chaudhary, B. D., S. N. Karar and R. K. Singh. 1977. Estimation genetic parameters in barley (Hordeum vulgar, L.,) II. Partial diallel analysis Theoretical and Applied Genetic 49: $153-156$

8. Cochran, W. C. and G. M. Cox. 1957. Experimental design. 2nd ed., John Wiley and Sons Inc., New York. U.S.A.

9. Darweesh, S. I. 2006. Genetic studies on breeding some Egyptian cotton varieties to resist Pink bollworm (Pectinophora gossyiella) M.Sc. Thesis, Env. Studies and Res. Inst., Ain Shams Univ., Egypt, 131 pp.

10. El-Zik, K.M. and P. M. Thaxton. 1989. Genetic improvement for resistance to pests and stresses in cotton. In R.E. Frisbie, K.M. El-Zik and L.T. Wilson, (Eds.), Integrated pest Management systems and cotton production. John Wiley\& Sons, New York, N.Y. p. 191-224

11. Gutierrez, J. C., M. G. Garia and J.Susin. 1988. Indentifcation of cultivars of cotton (G. hirsutum, L.). Inver. Agra. Produc., 3 (3), $297-313$.

12. Hair, J. F., R. E. Anderson and R. I. Taham. 1987. Multivariate data analysis with reading. Macmillan Publ. Co., New York.

13. Max, M. S. 2004. Genetic polymorphism for insect resistance attributes in some cotton genotypes. M.Sc. Thesis, Zagazig Univ., Egypt, 130 pp. 
14. Meredith, W. R. J., W. T. Pettigrew and J. J. Heithott. 1996. Sub-Okra, semismoothness, and Nectariless effect on cotton lint yield. Crop Sci. 36:22-25.

15. Seif El-Nasr, F. M. 1987. Breeding studies on cotton. Ph.D. Thesis, Fac. gric. Alexa. Univ, Egypt, 122 pp.

16. Smith, H. H. 1952. Fixing trangressive vigure in Nicotiana suclica heterosis. Iowa state Collage. Press. Ames, Tawa, U.S.A.

17. Verhalen, L. M. and J. C. Murray. 1969. A diallel analysis of several fiber property traits in upland cotton (G. hirsutum, L.) Crop Sci. 9: 311 - 315.

18. You, J. L. Liu and J. Z. Sun. 1998. Analysis of heterosis and its Components in inter-specific crosses between upland cotton and breeding lines developed from primititive race stocks (G. hirsutum, L.) Acta Agron. Sinica, 24 (6): $834-839$. 


\section{قوة الهجين والفعل الجينى لبعض الهجن فى القطن باستخدام الهجن التبادلية الجزئية ا - لصفة المقاومة للحشرات وتحليل العامل المتعدد لبعض الصفات المرتبطة بالمقاومة}

طلعت احمد الفقى' ، رمضان قرنى حرب` ، عزيزة محمد محمد سلطان'

$$
\begin{aligned}
& \text { | ـ معهد بحوث القطن - مركز البحوث الزراعية- جيزة } \\
& \text { r . قسم النبات الزراعى - كلية الزراعة- جامعة القاهة }
\end{aligned}
$$

تهدف هذة الدراسة لتقدير قوة الهجين والفعل الجينى لنسبة الاصابة وقد أستخدم تحليل العامل المتعدد لتحديد العلاقة المشاركة بين بعض الصفات المورفولوجية والنشريحية للساق ، الورقة، عنق الورقة، واللوزة مع نسبة الاصابة بديدان اللوز وقد أستخدم فى هذة الدراسة خمسة أصناف من القطن المصرى بالآضافة الى ثلاث سلالات من اقطان الآبلند الامريكية المقاومة للحشرات وقد نم التهجين بين الاباء بطريقة الهجن التبادلية الجزئية واجريت هذة الدراسة فى محطة البحوث الزراعية بالجيزة خلال ثلاثة مواسم 2002 ، 2004 2003 ويمكن تلخيص النتائج كما يلى: 1- اظهر تحليل التباين لنسبة الإصـابة بديدان اللوز وجود فروق معنويـة بين جميع التراكيب الوراثيـة

$$
\text { وبين الاباء وايضا بين الا باء والهجن وبين الجيل الاول والثاني. }
$$

r- كانت هناك قوة هجين معنوية موجبة بالنسبة لمتوسط الابوين لنسبة الاصـابة في معظم الهجن و كانت السيادة الفائقة هي التي تحكم هذه الصفة وكانت قيم الانخفاض الراجع للتربية سالبة وذلك

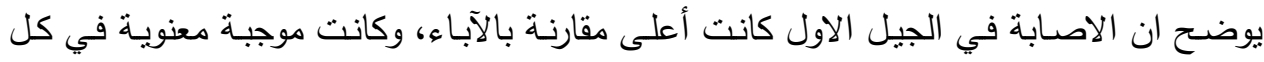

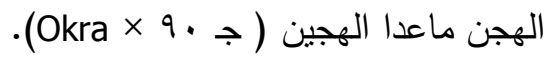

r- كان كلا من التباين الراجع للقدرة العامة والخاصة على الائتلاف لنسبة الاصابة عالى المعنوية مما يوضح اهمية التاثير غير المضيف للجينات لتحسين نسبة انخفاض الاصابة بالحشرات. ع- وجد ان افضل الاباء قدرة على الائتلاف لخفض نسبة الاصـابة لديدان اللوز السلالتين التابعتين للقطن الأمريكي Okra leaf ، Nectariless وكذلك جيزة .9 و ، وكانت الكفاءة الوراثية بمعناها الواسع لنسبة الإصـابة عالية في كلا الجيلين بينما كانت في المعنى الضيق متوسطة في الجيل الاول.

0- اظهر معامل الارتباط البسيط بين نسبة الإصابة لديدان اللوز والصفات المورفولوجية والتشريحية

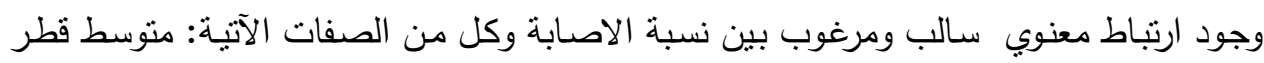

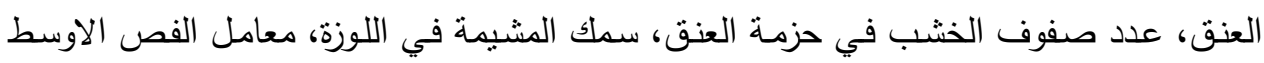

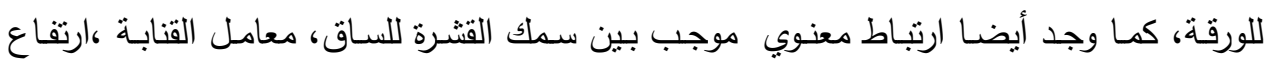

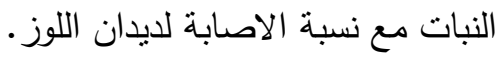


צ- أوضـح تحليل العامـل المتعدد (Multivariate) أو تحليل المكونـات الأساسية لثـانى صفات لها

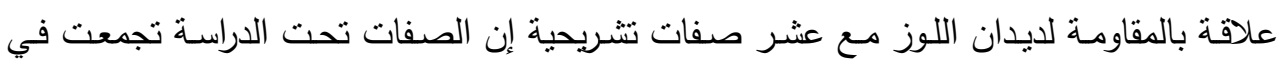

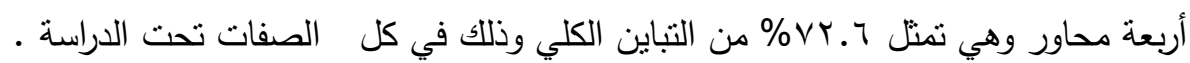

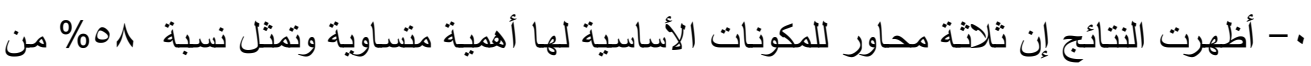

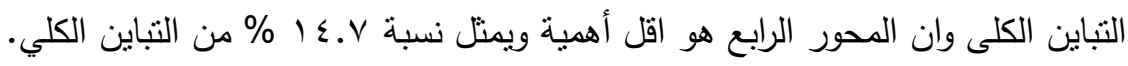

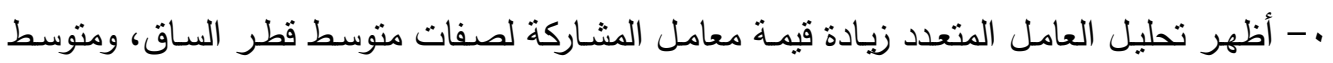
قطر النخاع مما يدل على أهميتها كمكون للتباين.

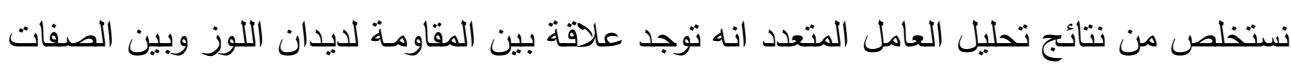

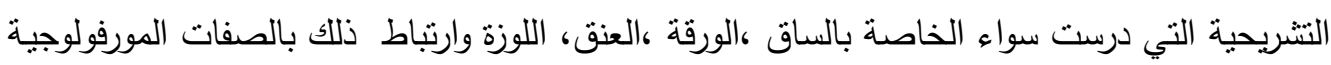

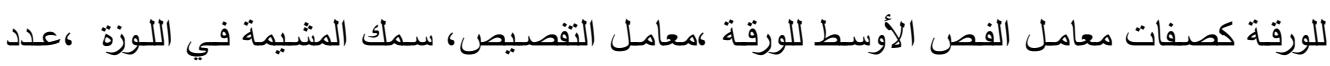
صفوف الخشب / الورقة، معامل القنابـة، منوسط قطر السـاق، منوسط قطر النخـاع، سمك القتشرة للساق، عدد صفوف الخشب في حزمة العنق، منوسط قطر العنق.

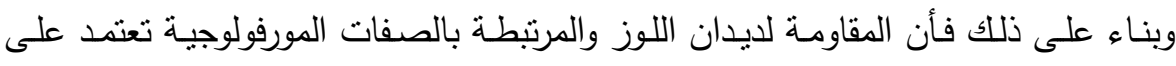
الصفات التشريحية لنبات القطن كسمك الشيمة في اللوزة وعدد صفوف الخشب في حزمـة العنق ومتوسط قطر عنق الورقة. 